\title{
Natural hazard management BUWELA
}

\author{
G. Holzinger \& H. Gruenwald \\ Forest Technical Service of Torrent and Avalanche Control, Austria
}

\begin{abstract}
In the field of activities of the local bureau of the Foresttechnical Service of Torrent and Avalanche Control for the Burgenland and Southern Lower Austria regional studies are gaining importance as an instrument of natural hazard management. In the scope of such studies up to now hydrologic regions such as river basins have been the working unit. This means that the processes were predefined and the field of interest has been chosen by geographic matters. For the geographic region "BUcklige Welt - WEchselLAnd" (BUWELA), we find a quite homogenous area, with different processes causing alpine natural hazards. This area covers different hydrologic units contributing to different supraregional river basins and thus exceeds the classic way of demarcation of project areas. Therefore in a first step the scientific basics for the whole area of about $1300 \mathrm{~km}^{2}$ are set up. The work of this first phase of the project is done by scientific institutions, which will deliver a global interdisciplinary database, describing the background for the processes occurring within the project area. In a second step process analyses will be put into effect. After a spatial distribution of type and intensity of relevant processes is known, the requirements for natural hazard management at the state of the art are given. With the knowledge of the different processes and their interaction protection strategies can be found by investigating the dealing of humans and society with these hazards. Finally this will lead to hazard mapping as well as development of regional protection strategies and detailed planning of measures. This new approach will turn over the procedure of natural hazard management from a bottom up to a top down viewpoint which allows implementing the regional interaction of various natural processes and allows decision makers to concentrate mitigation measures on the process itself instead of treating the symptoms of it.

Keywords: hydrology, natural hazard management, risk analysis, integrated watershed planning, river and watershed management.
\end{abstract}




\section{Introduction}

\subsection{Motivation and cause to start the project}

The instrument of the regional studies is used in the local bureau of torrent and avalanche control increasingly in order to receive decision bases in foreseeable time for concrete protection measures in the regions. In particular after the flood disaster of the year 2002 this procedure persisted since thereby technically wellfounded basics are offered for regional and supraregional political decisions.

In a first phase the scope of these regional studies have been local and regional river basins. They have been delineated as exactly drawn catchments of 50 up to $250 \mathrm{~km}^{2}$. The new approach of the BUWELA project is to ignore in a first step these hydrologic boundaries. In fact the wherefores for defining the project area have been to find a quite homogenous area, where the relevant attributes or characteristics of the landscape draw a small structured pattern.

\section{The project area}

The project represents a core area of the local bureau of torrent and avalanche control. Diverse hazards led to the facts that at the end of the 19th century extensive protection measures were set up. Accordingly the activity of the torrent control service is correspondingly intense, in particular in the preservation of the structures, however, also, due to the settlement pressure, in the set up of new protection measures. This led further to the fact that hazard maps were provided early and meanwhile must urgently be submitted to a revision.

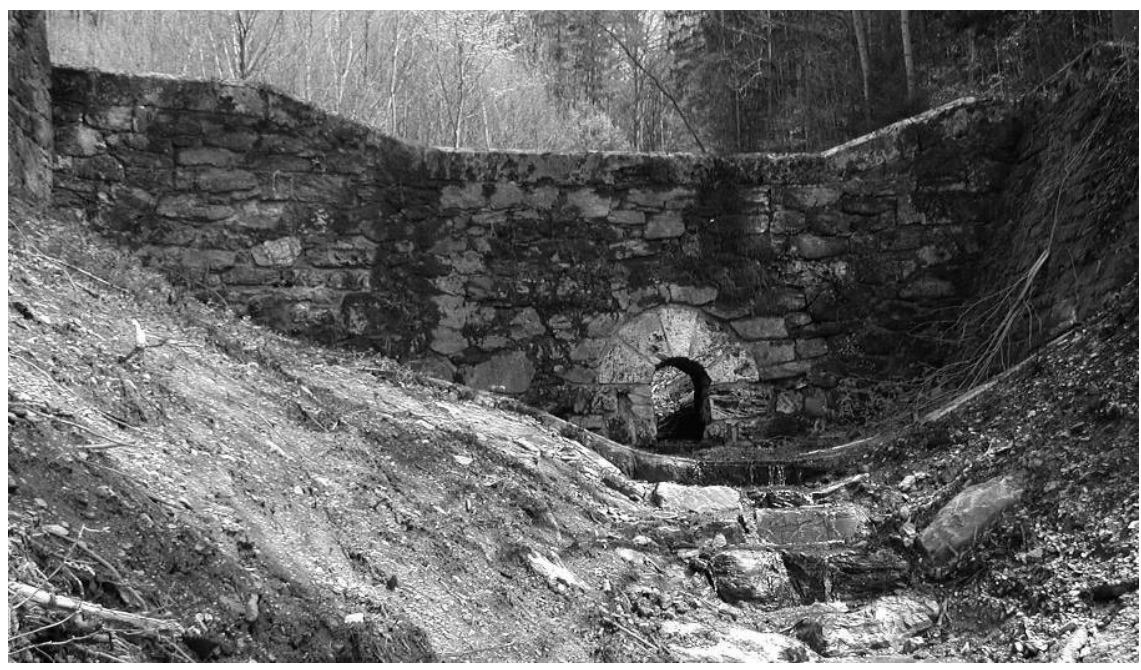

Figure 1: Check dam in the Kreuzleitenbach, one of the oldest technical structures in the scope of natural hazard protection (Year of construction 1884). 
Also from the technical viewpoint this area makes large demands against the intention to reach optimal protection for torrent dangers due to the hydrological and geological and/or geomorphologic conditions. As examples the ranges with phyllitic bed rock, the high thunderstorm frequencies and intensities, as well as the partly intense protection activities since the existence of the torrent control service in this field shall be mentioned.

The project area is situated in the eastern foothills of the alpine arch and represents the last up hills at the edge of the Pannonian plain. It covers the landscapes Bucklige Welt as well as the Wechselland and is extended in the north-west to the Rosaliengebirge. The area for this project covers $1.300 \mathrm{~km}^{2}$, the elevation above sea level reaches from $225 \mathrm{~m}$ up to $1745 \mathrm{~m}$.

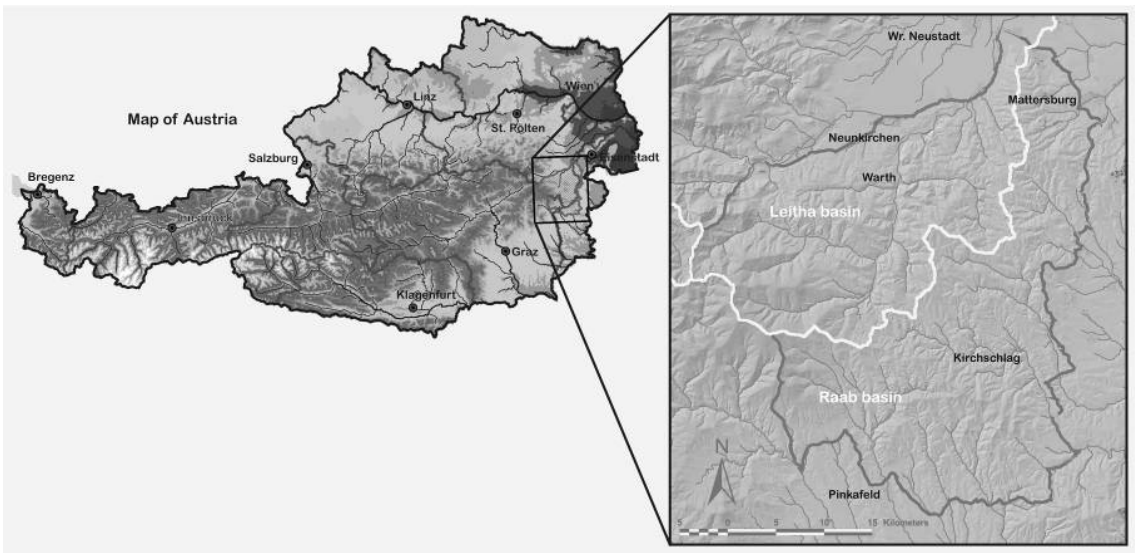

Figure 2: $\quad$ Map of the project area.

\section{Methodology}

First of all an Exposure analysis as described by Hübl [1] has been set up. The main project is divided into three phases. In the first phase the scientific fundamentals for the whole project area shall be collected within the basic modules. This work is done by scientific institutions in an interdisciplinary way. In the second phase on the base of the results and the generated data of phase I functional modules within a geographical classification of natural landscapes will be carried out. In the scope of the functional modules on one side the precipitation - runoff - conditions will be investigated. On the other hand with consideration of mass movements on the scale level of the torrent catchments the relevant torrential processes and their effect on spatial relevant areas. In this way the problems relevant for hazard zoning are pointed out qualitatively and quantitatively in their spatial distribution. This leads to the concluding phase III, in which the hazard maps are provided and results of the project are processed for future tasks of planning. 


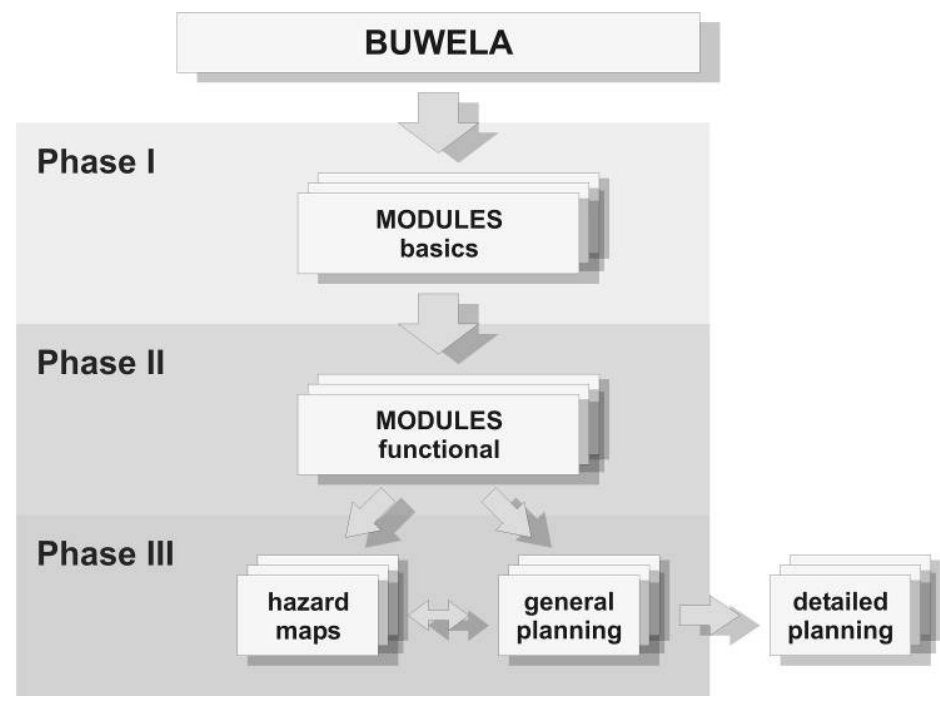

Figure 3: $\quad$ Project flowchart.

\section{Exposure analysis}

For the BUWELA project for an assessment of spatial relevance of natural hazard on humans an Exposure analysis was carried out. Thereby the protection aim in the project area and the intensity of control work in the individual torrents are regarded. On the basis of land use data in a GIS-system a spatial distribution of protection goals is compiled and from it the spatial relevance is derived. Therefore for the different types of land use (Austria: Land use and Living Space, delivered by Seger [4]) protection aim classes have been defined. As a second step the spatial distribution of these classes has been derived.

Table 1: $\quad$ Protection aim classes.

\begin{tabular}{|l|l|}
\hline class & description \\
\hline 3 & $\begin{array}{l}\text { All types of housing development area, as well as building land } \\
\text { where a high number of persons can be expected }\end{array}$ \\
\hline 2 & $\begin{array}{l}\text { Traffic, congeries of buildings within agricultural land, leisure } \\
\text { facilities with increased person arising }\end{array}$ \\
\hline 1 & Other areas, where on gatherings of people is to be counted \\
\hline 0 & Remaining areas, which do not correspond to the upper descriptions \\
\hline
\end{tabular}

This allocation of land use types to protection aim classes leads to a very small structured pattern of protection aim classes. In order to achieve a general statement about the spatial relevance of natural hazards, the detailed result is processed in a raster with a mesh size of $250 \mathrm{~m}$. This extent of raster cells has been selected, since an area of this size appears suitable as basis for further 
planning. Each raster gets the highest protection aim arising within the area of the cell assigned. This leads to a general representation of the distribution of the protection aim classes in the project area, which is suitable for the evaluation of the spatial relevance of natural hazards on human activity whereby all protection aim classes, except class 0 , are treated as relevant areas.

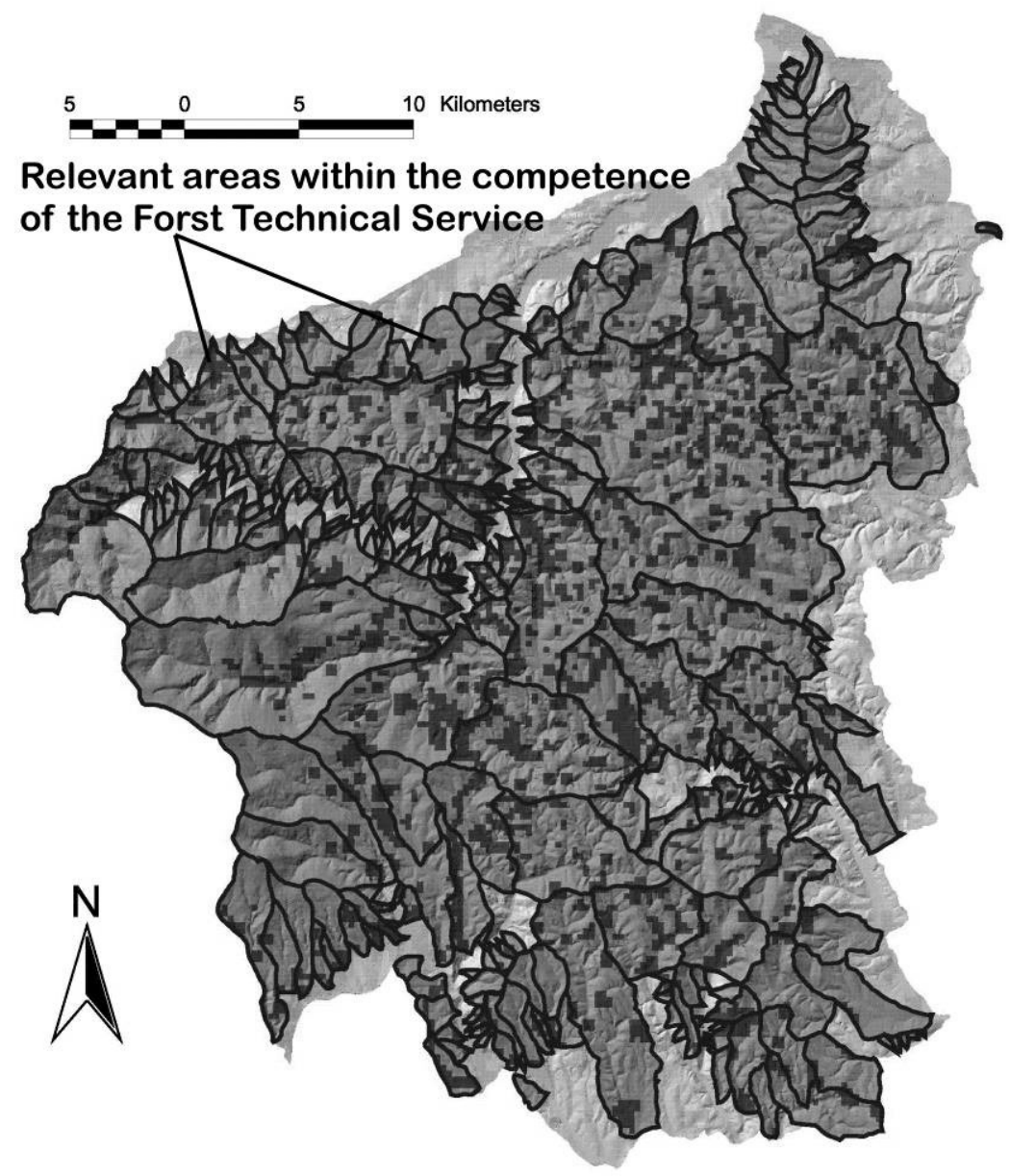

Figure 4: Relevant areas.

\section{Basic modules within phase I}

\subsection{Hydrology}

In the basic module "hydrology" (project partner: Vienna University of Technology) design precipitation is to be derived from the evaluation of existing data, whereby from time series of many years of climate and weather data typical 
precipitation scenarios are to be deduced, which lead to the occurrence of disaster events in torrents, attending to the return period. The results are to be prepared quantitative and qualitative with their spatial distribution in a way to use them directly for precipitation runoff modelling within the functional modules.

\subsection{Geology and geomorphology}

The goal of the basic module "geology and geomorphology" (project partner: Geological Survey of Austria) should be to receive the relevant information about the bed load dynamics. This covers on the one hand the bed rock with its weathering dynamics as well as the in-situ substrate and the surface weathering products; on the other hand it treats the recent dynamics of forming the macro relief recognizable from morphologic micro shape. This information is to be prepared in such a way that the general questions about potential bed load supply (quantitative and qualitative) and current bed load dynamics are thus answered that in the functional modules accurate problem definitions with accurate spatial allocation can be derived.

\subsection{Soil, vegetation and land use}

In the basic module "soil, vegetation and land use" (project partner: Federal Research and Training Centre for Forests, Natural Hazards and Landscape) on the one hand input data for the precipitation-runoff-modelling in the functional modules are generated, on the other hand consolidated findings about the stability of the substrate against erosion, due to vegetation and land use are to be received. In especial runoff coefficient classes as developed by Markart et al. [3] are drawn out for the project area.

\section{Functional modules within phase II}

\subsection{Precipitation-runoff-modelling}

Goal of this module is the determination of design discharges for river locations in the project area. The results treating discharge are in their quantitative as well as their qualitative description of importance, i.e. discharge hydrographs are to be provided. Therefore the Forest technical Service defines points of interest (deduced from the exposure analysis) where the compiling of discharge hydrographs is necessary. Basis and inputs for this part are the data and results collected in the basic modules. In addition, these results are checked on plausibility by existing observations (well-known disaster events, silent witnesses) in the catchments areas, to examine and to adapt the models in a neat way.

So the first step is to set up the river systems for modelling by the results of the exposure analysis and to set up the model parameters by the results of the basic modules. Second is to calibrate the calculation models by known flood events, then to get the design discharge for predefined return periods by modelling the precipitation scenarios from the basic module hydrology. 


\subsection{Torrential processes}

Goal of this module is to compile the relevant processes in the project area. Based on these processes the accurate posing of the problems can be derived. The results from this module shall ensure that the conceptual formulation for further hazard mapping and regional planning can be drawn properly. For the development of this functional module the results from the basic modules geology and geomorphology and soil, vegetation and land use, as well as from the preceding functional module precipitation-runoff-modelling are at the disposal.

The main scope of this module will be to derive potential floodplains, potential retention areas as well as to develop exact knowledge about bed load dynamics, as erosion, deposition and transportation of bed load material.

While up to now more or less the whole project area has been of interest, for this module the results of the exposure analysis draw the points of interest. So the technical work within this module concentrates on the relevant areas as derived there.

\section{Outlook to the future}

The BUWELA project will run until 2011. Within phase III, 54 hazard maps have to be drawn. Up to now high interest by politics and decision makers in the region can be seen. One point of view to the BUWELA project is the cooperation of officials within federal competence as well as provincial competence. As nature cannot be delineated by demands of public management this project offers the chance to do hazard management using a holistic approach and offering integrative results for political decisions on a solid scientific base. BUWELA can be seen as a pilot project, which shall draw out the potential of supraregional interdisciplinary approaches within the field of natural hazard management. With the help of the experiences from BUWELA, it shall be possible to bring the field of natural hazard management on to a new integrative approach and define the state of the art in a modern way.

So the following citation will fit perfectly as final statement: "Die Zeiten für den Planer sind anspruchsvoll - aber interessant wie noch nie" ("Times for planners are demanding - but interesting as never before"), written by Kettl [2], more then 20 years ago and still up-to-date.

\section{References}

[1] Hübl, J., Sicherheitsplanung zum Schutz vor Murgängen, Habilitation an der Universität für Bodenkultur Wien, University of Natural Resources and Applied Life Sciences, Vienna, 2001

[2] Kettl, W., Vom Verbauungsziel zur Bautypenentwicklung Wildbachverbauung im Umbruch; Wildbach- und Lawinenverbau, 48(SH), pp. 61-98, 1984 
[3] Markart, G., B. Kohl, B. Sotier, T. Schauer, Bunza, G. \& Stern, R., Provisorische Geländeanleitung zur Abschätzung des Oberflächenabflussbeiwertes auf alpinen Boden-/Vegetationseinheiten bei konvektiven Starkregen (Version 1.0), BFW Dokumentation, 3/2004, pp. 1-88, 2004

[4] Seger, M., Realraumanalyse Österreichs - eine digitale thematische Erfassung der Landnutzung und des Landschaftsverbrauchs. Österreich in Geschichte und Literatur mit Geographie, 44(2), pp. 109-119, 1999 